\title{
BCL2L10 is frequently silenced by promoter hypermethylation in gastric cancer
}

\author{
RINTARO MIKATA ${ }^{1}$, KENICHI FUKAI $^{1}$, FUMIO IMAZEKI $^{1}$, MAKOTO ARAI $^{1}$, \\ KEIICHI FUJIWARA ${ }^{1}$, YUTAKA YONEMITSU ${ }^{1}$, KAIYU ZHANG ${ }^{1}$, YOSHIHIRO NABEYA ${ }^{2}$, \\ TAKENORI OCHIAI ${ }^{2}$ and OSAMU YOKOSUKA ${ }^{1}$
}

Departments of ${ }^{1}$ Medicine and Clinical Oncology, and ${ }^{2}$ Frontier Surgery, Graduate School of Medicine, Chiba University, 1-8-1 Inohana, Chuo Ward, Chiba 260-8670, Japan

Received November 12, 2009; Accepted February 9, 2010

DOI: $10.3892 /$ or_00000814

\begin{abstract}
In gastric cancer, several tumor suppressor and tumor-related genes are silenced by aberrant methylation. Previously, we demonstrated that BCL2L10, which belongs to the pro-apoptotic Bcl-2 family, was transcriptionally repressed by promoter hypermethylation and that its overexpression caused apoptosis and growth inhibition of gastric cancer cells. In this study, we investigated the methylation status of BCL2L10 and its expression in 21 gastric cancer tissues and corresponding non-neoplastic mucosae along with the methylation status of p16, RUNX3, and hMLH1 genes by using methylation specific PCR In addition, we examined the association between the methylation status of each gene and the expression of EZH2, which was associated with DNA methylation of its target genes. As a result, aberrant methylation of BCL2L10 was detected in $38 \%$ of gastric cancer and in $24 \%$ of corresponding non-neoplastic mucosae and correlated with low expression of BCL2L10. Methylation of p16, RUNX3, and hMLH1 was found in gastric cancer and in corresponding non-neoplastic mucosae at almost similar frequencies as previous reports. Expression of EZH2 was detected more frequently in tumors $(48 \%)$ as compared to corresponding non-neoplastic mucosae $(10 \%)(\mathrm{p}=0.006)$, however, no significant difference was found between expression of $\mathrm{EZH} 2$ and the methylation frequency of each gene. In conclusion, our data suggest that silencing of BCL2L10 by aberrant methylation is a common feature in gastric cancer and its inactivation may be involved in the early steps of gastric carcinogenesis.
\end{abstract}

Correspondence to: Dr Fumio Imazeki, Department of Medicine and Clinical Oncology, Graduate School of Medicine, Chiba University, Inohana 1-8-1, Chuo Ward, Chiba 260-8670, Japan E-mail: imazekif@faculty.chiba-u.jp

Key words: methylation, gastric cancer, BCL2-like10, EZH2

\section{Introduction}

Transcriptional silencing of tumor suppressor genes by promoter hypermethylation is a common feature of human cancer. In gastric cancer, several tumor suppressor and tumor-related genes, including CDKN2A (p16) (1), RUNX3 (2) and hMLH1 (3), have been reported to be silenced by aberrant methylation. Recently, the number of genes known to be inactivated by DNA methylation in gastric cancer, such as genes related to cell cycle control (4), cell proliferation (5) and apoptosis (6), have accumulated. We previously analyzed the genes induced by the demethylating agent 5aza-2'-deoxycytidine (DAC) in gastric cancer cell lines using a cDNA microarray containing 30,000 genes. We found that BCL2L10, which belongs to the proapoptotic Bcl-2 family, was transcriptionally repressed by promoter hypermethylation (7). BCL2L10 (also called Diva) has been reported to directly interact with Apaf-1 and to displace Bcl- $\mathrm{X}_{\mathrm{L}}$, suggesting it inhibits $\mathrm{Bcl}-\mathrm{X}_{\mathrm{L}}$ function and promotes apoptosis (8). Conversely, it was also reported that BCL2L10 had an anti-apoptotic effect on human glioma cells (9). The previous observations that BCL2L10 was associated with either the anti-apoptotic proteins $\mathrm{Bcl}-2$ and $\mathrm{Bcl}-\mathrm{X}_{\mathrm{L}}$ or with the proapoptotic protein Bax (10) suggest that BCL2L10 could exert different effects on cells under certain circumstances depending on the cellular context. Previously, we demonstrated that overexpression of BCL2L10 caused apoptosis and growth inhibition of gastric cancer cells (7). Gastric carcinogenesis is thought to consist of a multi-step process composed of genetic and epigenetic disorders. Methylationmediated down-regulation of BCL2L10 may be one such epigenetic event involved in gastric carcinogenesis.

Recently, it was reported that overexpression of EZH2 (Enhancer of Zeste homolog 2), which is a member of the polycomb group (PcG) of proteins, occurred in a variety of human malignancies including gastric cancer $(11,12)$. The PcG proteins are believed to act as multiprotein complexes that repress target gene expression through modification of chromatin structure. EZH2 is the catalytically active component of polycomb repressive complex 2 (PRC2) and is capable of methylating lysine 9 (H3K9) and lysine 27 (H3K27) of histone H3 $(13,14)$. Moreover, EZH2 was 
Table I. Primer sets for MSP.

\begin{tabular}{|c|c|c|c|c|c|}
\hline Primer set & $\begin{array}{l}\text { Genome } \\
\text { position }\end{array}$ & Sequence & $\begin{array}{l}\text { Product } \\
\text { size }\end{array}$ & $\begin{array}{l}\text { Annealing } \\
\text { temperature }\end{array}$ & Cycles \\
\hline \multicolumn{6}{|l|}{ MSP } \\
\hline BCL2L10-M (S) & -70 & AATATATCGGGGGTCGGGGGTC & 180 & 62 & 35 \\
\hline BCL2L10-M (AS) & +110 & AACTCGATACGCTCCCGCAACG & & & \\
\hline BCL2L10-U (S) & -70 & AATATATTGGGGGTTGGGGGTT & 186 & 59 & 35 \\
\hline BCL2L10-U (AS) & +116 & AАCAАCAАСТСААТАСАСТСССА & & & \\
\hline P16-M (S) & +167 & TTATTAGAGGGTGGGGCGGATCGC & 150 & 65 & 35 \\
\hline P16-M (AS) & +316 & GACCCCGAACCGCGACCGTAA & & & \\
\hline P16-U (S) & +167 & TTATTAGAGGGTGGGGTGGATTGT & 151 & 60 & 35 \\
\hline P16-U (AS) & +317 & CAACCCCAAACCACAACCATAA & & & \\
\hline RUNX3-M (S) & -262 & TTACGAGGGGCGGTCGTACGCGGG & 220 & 65 & 35 \\
\hline RUNX3-M (AS) & -42 & AAAACGACCGACGCGAACGCCTCC & & & \\
\hline RUNX3-U (S) & -262 & TTATGAGGGGTGGTTGTATGTGGG & 220 & 63 & \\
\hline RUNX3-U (AS) & -42 & AAAACAACCAACACAAACACСТCC & & & \\
\hline hMLH1-M (S) & -675 & TATATCGTTCGTAGTATTCGTGT & 153 & 60 & 35 \\
\hline hMLH1-M (AS) & -523 & TCCGACCCGAATAAACCCAA & & & \\
\hline hMLH1-U (S) & -721 & TTTTGATGTAGATGTTTTATTAGGGTTGT & 124 & 60 & 35 \\
\hline hMLH1-U (AS) & -598 & АССАССТСАТСАТААСТАСССАСА & & & \\
\hline
\end{tabular}

Sense (S) and antisense (AS) primers used for PCR amplification and the size of respective PCR products are shown. Genome position indicates the nucleotide position relative to the transcription start site.

reported to be required for DNA methylation of its target genes through recruitment of DNA methyltransferases (15).

In this study, we clarified the methylation status of BCL2L10 and its expression in gastric cancer tissues and corresponding non-neoplastic mucosae by performing methylation-specific PCR (MSP) and real-time RT-PCR. We also compared it with the methylation status of p16, RUNX3, and hMLH1 genes that have been well documented in gastric cancer. In addition, to determine whether EZH2 influenced the methylation status of these four genes, we examined the association between the methylation status of each gene and the expression level of EZH2.

\section{Materials and methods}

Tissue samples and DNA extraction. Gastric cancer tissues and corresponding non-neoplastic mucosae were obtained from 21 patients (male 14; female 7; median age 70 years old; range, 56-85 years) who underwent surgical resection at Chiba University Hospital, Chiba, Japan between 2005 and 2006. All resected specimens were frozen immediately in liquid nitrogen and stored at $-80^{\circ} \mathrm{C}$ until use. Histopathological examination was performed according to the Japanese Classification of Gastric Carcinoma (16). Based on the histological findings, the 21 tumors were classified as 4 well differentiated, 6 moderately differentiated, and 11 poorly differentiated (including signet ring cell and mucinous carcinomas) adenocarcinomas. We microscopically confirmed that the tumor specimens used in this study consisted mainly ( $>80 \%$ ) of carcinoma tissue. The status of $H$. pylori infection was also histologically confirmed. All patients had given informed consent for their participation, and the Ethics Committee approved these studies.

Sodium bisulfite DNA sequencing and methylation specific PCR (MSP). Genomic DNAs were extracted using a QIAamp DNA Mini kit (Qiagen, Hilden, Germany) according to the instructions of the manufacturer. Using extracted DNA, bisulfite modification of DNA $(1 \mu \mathrm{g})$ was performed using the CpGenome $^{\mathrm{TM}}$ DNA modification kit (Chemicon International Inc., CA, USA) according to the manufacturer's instructions. Modified DNA was purified using a DNA purification kit (Qiagen). To examine the DNA methylation status of the BCL2L10, p16, RUNX3, and hMLH1 genes, we performed MSP. For detection of aberrant methylation of these genes, modified DNA was amplified using AmpliTaq Gold DNA Polymerase (Applied Biosystems), and primers specific for the methylated and unmethylated sequences of each gene (17-19) are shown in Table I. Location of MSP primers for BCL2L10 in its CpG island is shown in Fig. 1. PCR products $(5 \mu \mathrm{l})$ were run on a $3 \%$ agarose gel and visualized by SYBRGreen (FMC, Rockland, ME) staining. CpGenome Universal Methylated DNA (Chemicon International, Temecula, CA) was used as a positive control for methylation.

Semiquantitative RT-PCR and real-time RT-PCR. Total RNA was extracted with an RNeasy Mini Kit (Qiagen) according to the manufacturer's instructions. First strand cDNA was 


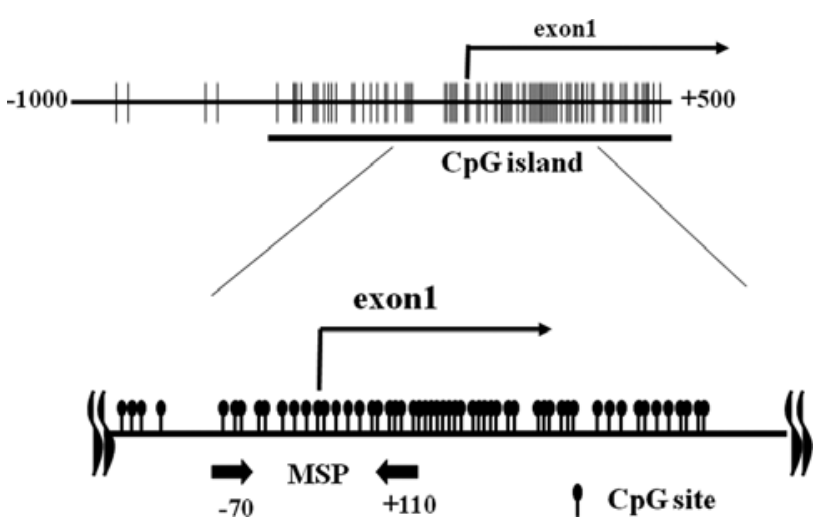

Figure 1. Genomic structure around the 5'CpG island of BCL2L10 from -1000 to +500 with respect to the transcription start site $(+1)$. A vertical bar indicates a $\mathrm{CpG}$ site.

synthesized from $1 \mu \mathrm{g}$ of total RNA by reverse transcription with random oligonucleotide primers and Superscript II reverse transcriptase (Invitrogen) according to the manufacturer's instructions, and the cDNA was diluted to $200 \mu \mathrm{l}$ with sterile, ultrapure water. The product $(2 \mu 1)$ was then amplified by PCR using the primer set for EZH2 as previously reported (20). After an initial denaturation at $95^{\circ} \mathrm{C}$ for $2 \mathrm{~min}$, PCR was performed in a $25-\mu 1$ reaction volume for 30 cycles under the following conditions: $95^{\circ} \mathrm{C}$ for $30 \mathrm{sec}, 62^{\circ} \mathrm{C}$ for $30 \mathrm{sec}, 72^{\circ} \mathrm{C}$ for $60 \mathrm{sec}$, and an extension at $72^{\circ} \mathrm{C}$ for $5 \mathrm{~min}$. PCR products $(5 \mu 1)$ were run on a $3 \%$ agarose gel and visualized by SYBR-Green staining. RNA samples were also amplified using $\beta$-actin gene primers as control. Real-time PCR was performed for the BCL2L10 gene using Taqman ${ }^{\circledR}$ Gene Expression Assays Inventoried, purchased from Applied
Biosystems Japan (Tokyo, Japan). The BCL2L10 gene was amplified on the same plate as the B-actin reference using the TaqMan Universal PCR Master Mix and the ABI Prism 7000 Sequence Detection Systems (Applied Biosystems), and relative mRNA amounts were determined. Briefly, we normalized each set of samples using the difference in threshold cycles $\left(\Delta \mathrm{C}_{\mathrm{T}}\right)$ between each gene and the $B$-actin gene $\left(\Delta \mathrm{C}_{\mathrm{Tsample}}=\Delta \mathrm{C}_{\mathrm{Tthe} \mathrm{gene}}-\Delta \mathrm{C}_{\mathrm{TB} \text {-actin }}\right)$. cDNA from the cell line, which clearly expressed the mRNA of each gene and the $B$-actin gene, was used as the calibration sample $\left(\Delta \mathrm{C}_{\text {Tcalibration }}\right)$. Relative mRNA levels were calculated by the expression $2^{-\Delta \Delta C T}$, where $\Delta \Delta \mathrm{CT}=\Delta \mathrm{C}_{\mathrm{Tsample}}-\Delta \mathrm{C}_{\mathrm{T} \text { calibration }}$.

Statistical analysis. Differences were analyzed statistically by $\chi^{2}$ tests and Mann-Whitney $U$ tests. Results were considered statistically significant at $\mathrm{p}<0.05$.

\section{Results}

Methylation status of BCL2L10, p16, RUNX3, and hMLH1. Promoter methylation of BCL2L10 was detected by MSP in $38 \%$ ( 8 of 21 ) of gastric cancer tissues and in $24 \%$ (5 of 21) of corresponding non-neoplastic mucosae (Fig. 2A and Table II). In 4 cases, BCL2L10 methylation was detected both in gastric cancer tissues and in corresponding non-neoplastic mucosae. CpG island methylation of p16, RUNX3, and hMLH1 was found in both neoplastic and non-neoplastic gastric mucosae, distributed as follows: $43 \%$ (9 of 21) and $24 \%$ (5 of 21) for p16, $48 \%$ (10 of 21) and 19\% (4 of 21) for RUNX3, and 10\% (2 of 21) and 5\% (1 of 21) for hMLH1, respectively (Fig. 2A and Table II). RUNX3 methylation was more frequent in tumors than in non-neoplastic mucosae $(\mathrm{p}=0.049)$ (Table III), especially in histologically undiffe-

$\mathbf{A}$

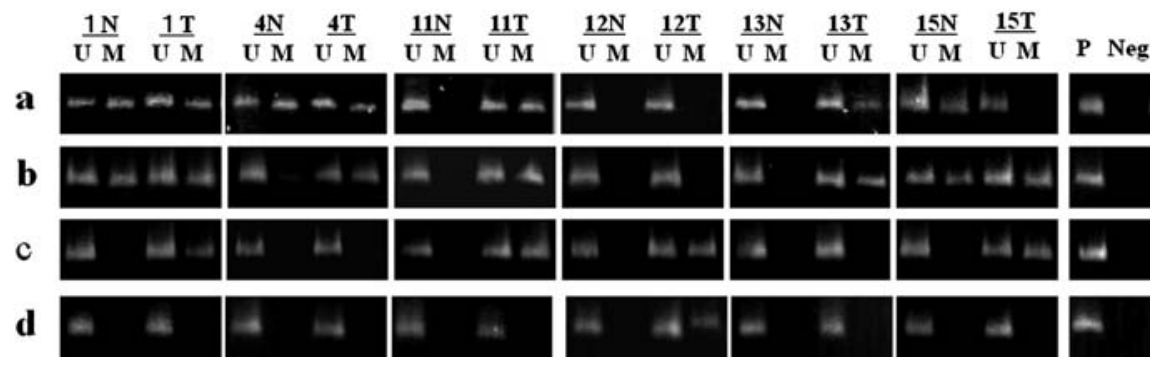

B

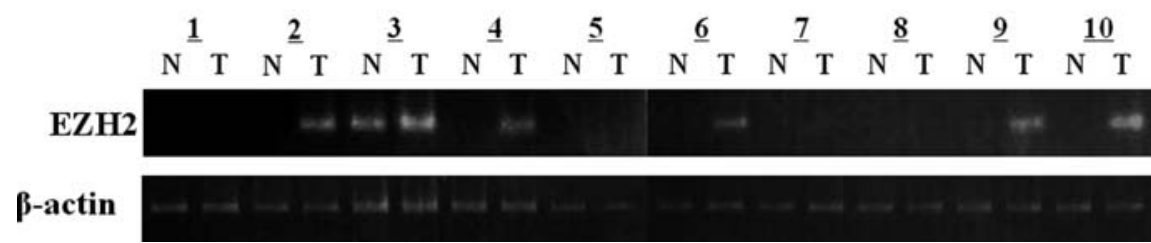

Figure 2. (A) Representative results of methylation-specific PCR (MSP) for BCL2L10 (a), p16 (b), RUNX3 (c), and hMLH1 (d). The numbers of gastric cancer cases are shown above the corresponding lanes. N, non-neoplastic tissue; T, tumor tissue; U and M, MSP analysis specific for unmethylated and methylated sequences, respectively; P, positive control; Neg, negative control (water). (B) Representative results of semiquantitative RT-PCR of EZH2 transcripts in gastric cancer. The numbers of gastric cancer cases are shown above the corresponding lanes. The amplification of $\beta$-actin mRNA was performed to validate the quality of the samples. $\mathrm{N}$, non-neoplastic tissue; $\mathrm{T}$, tumor tissue. 


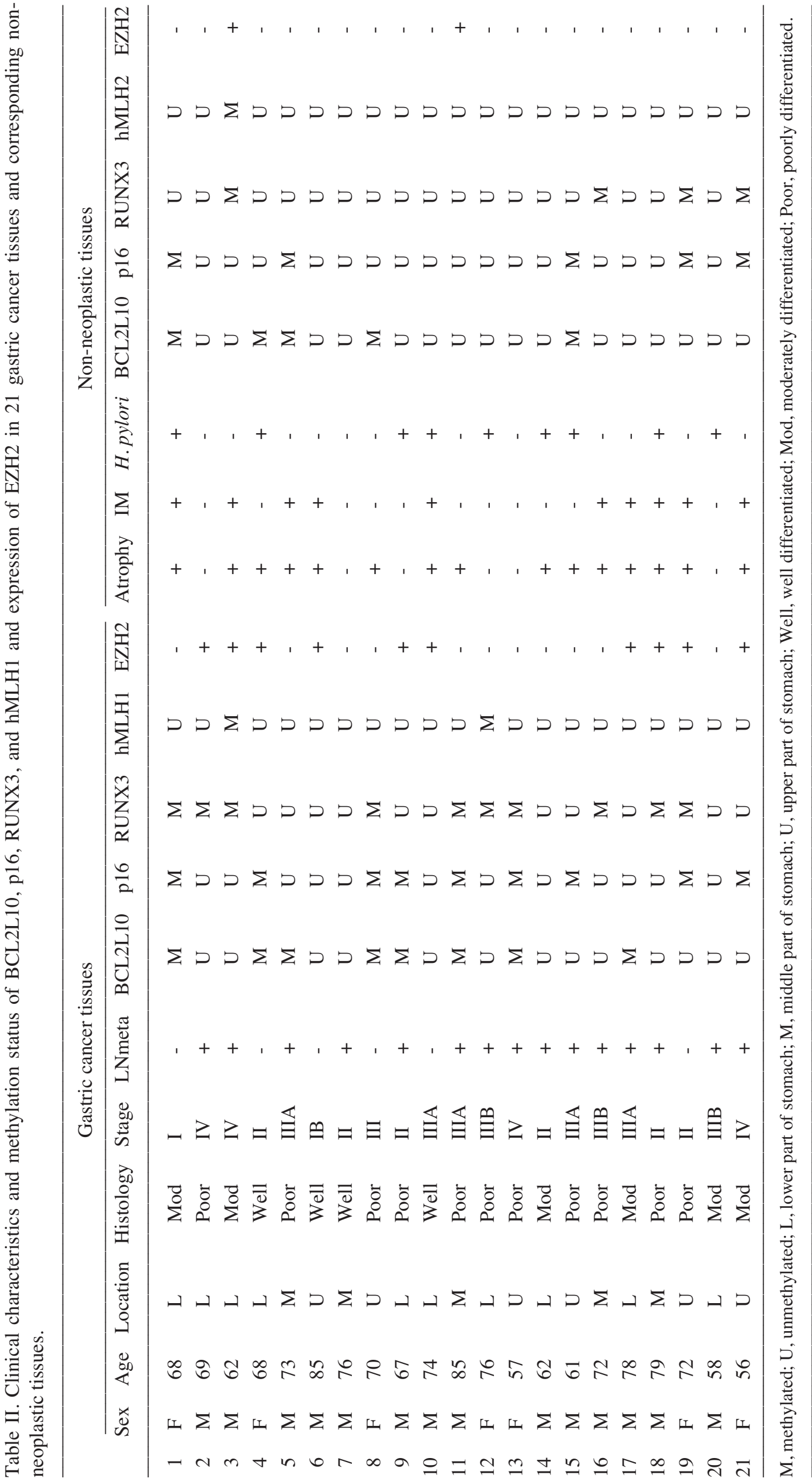


Table III. Correlation between methylation frequency or expression of EZH2 in gastric cancer tissues and those in corresponding non-neoplastic tissues.

\begin{tabular}{lccc}
\hline & $\begin{array}{c}\text { Gastric cancer } \\
\text { tissues }\end{array}$ & $\begin{array}{c}\text { Non-neoplastic } \\
\text { tissues }\end{array}$ & p-value \\
\hline BCL2L10 & 8 & 5 & 0.32 \\
$\quad$ Methylated & 13 & 16 & \\
Unmethylated & & & \\
p16 & 9 & 5 & 0.19 \\
Methylated & 12 & 16 & \\
Unmethylated & & & \\
RUNX3 & 10 & 4 & 0.0495 \\
Methylated & 11 & 17 & \\
Unmethylated & & & \\
hMLH1 & 2 & 1 & 0.55 \\
Methylated & 19 & 20 & \\
Unmethylated & & & \\
EZH2 expression & & 2 & 0.006 \\
Present & 10 & 19 & \\
Absent & 11 & & \\
\hline
\end{tabular}

Differences were analyzed statistically by $\chi^{2}$ test.

rentiated tumors as opposed to differentiated ones $(\mathrm{p}=0.02)$. BCL2L10 methylation did not correlate with any clinicopathological characteristics including sex, age, location, histology, stage, or $\mathrm{N}$ grade, but did correlate with p16 methylation. p16 methylation was present in 6 of 8 tumors containing methylated BCL2L10 ( $\mathrm{p}=0.02)$ (Table IV).

Regarding non-neoplastic gastric mucosae, BCL2L10 methylation did not correlate with sex, age, location, presence of intestinal metaplasia (IM), presence of atrophy or H. pylori infection, but did correlate with p16 methylation (Table V). RUNX3 methylation was found only in the subjects with IM, not in those without IM $(\mathrm{p}=0.02)$. On the other hand, BCL2L10 and p16 methylation were detected in the subjects with atrophy regardless of the presence of IM. No methylation of these genes was detected in those without atrophy. With regard to methylation frequency of each gene, no significant difference was found between subjects either with or without H. pylori infection.

Relationship between promoter methylation and $m R N A$ expression of BCL2L10 gene. BCL2L10 expression was analyzed in 21 gastric cancer tissues and corresponding nonneoplastic mucosae by real-time RT-PCR. The expression level of BCL2L10 in tumors was significantly lower than in corresponding non-neoplastic mucosae $(\mathrm{p}=0.048)$ (Fig. 3A). Among the 21 tumors, 8 tumors with methylated BCL2L10 showed significantly lower expression of BCL2L10 than the 13 tumors without methylation ( $p=0.005$, Fig. 3B). Among the 21 corresponding non-neoplastic mucosae, 5 subjects
Table IV. Correlation of methylation status of BCL2L10 with clinicopathological characteristics and methylation status or expression of p16, RUNX3, hMLH1, and EZH2 in gastric cancer tissues.

\begin{tabular}{|c|c|c|c|}
\hline \multirow{2}{*}{$\begin{array}{l}\text { Clinicopathological } \\
\text { characteristics }\end{array}$} & \multicolumn{2}{|c|}{$\begin{array}{c}\text { Methylation } \\
\text { status of BCL2L10 }\end{array}$} & \multirow[b]{2}{*}{ p-value } \\
\hline & M & $\mathrm{U}$ & \\
\hline \multicolumn{4}{|l|}{ Sex } \\
\hline Male (14) & 4 & 10 & 0.2 \\
\hline Female (7) & 4 & 3 & \\
\hline \multicolumn{4}{|l|}{ Age } \\
\hline$\leq 65(6)$ & 1 & 5 & 0.2 \\
\hline$>65(15)$ & 7 & 8 & \\
\hline \multicolumn{4}{|l|}{ Location } \\
\hline Upper (6) & 2 & 4 & \\
\hline Middle (5) & 2 & 3 & 0.96 \\
\hline Lower (10) & 4 & 6 & \\
\hline \multicolumn{4}{|l|}{ Histological type } \\
\hline Differentiated & 3 & 7 & 0.47 \\
\hline Undifferentiated & 5 & 6 & \\
\hline \multicolumn{4}{|l|}{ Stage } \\
\hline I or II (8) & 3 & 5 & 0.96 \\
\hline III or IV (13) & 5 & 8 & \\
\hline \multicolumn{4}{|l|}{$\mathrm{N}$ stage } \\
\hline N0 (6) & 3 & 3 & 0.47 \\
\hline $\mathrm{N} 1,2,3(15)$ & 5 & 10 & \\
\hline \multicolumn{4}{|l|}{ p16 methylation } \\
\hline Present (9) & 6 & 3 & 0.02 \\
\hline Absent (12) & 2 & 10 & \\
\hline \multicolumn{4}{|l|}{ RUNX3 methylation } \\
\hline Present (10) & 4 & 6 & 0.86 \\
\hline Absent (11) & 4 & 7 & \\
\hline \multicolumn{4}{|l|}{ hMLH1 methylation } \\
\hline Present (2) & 0 & 2 & 0.24 \\
\hline Absent (19) & 8 & 11 & \\
\hline \multicolumn{4}{|l|}{ EZH2 expression } \\
\hline Present (10) & 3 & 7 & 0.46 \\
\hline Absent (11) & 5 & 6 & \\
\hline
\end{tabular}

Differences were analyzed statistically by $\chi^{2}$ test. M, methylated; $\mathrm{U}$, unmethylated.

with methylated BCL2L10 also showed significantly lower expression of BCL2L10 than the 16 subjects without methylation ( $p=0.02$, Fig. $3 \mathrm{C})$.

EZH2 expression in gastric cancer and relationship with DNA methylation. EZH2 mRNA abundantly existed in 10 
Table V. Correlation of methylation status of BCL2L10 with clinicopathological characteristics and methylation status or expression of p16, RUNX3, hMLH1, and EZH2 in non-neoplastic tissues.

\begin{tabular}{|c|c|c|c|}
\hline \multirow{2}{*}{$\begin{array}{l}\text { Clinicopathological } \\
\text { characteristics }\end{array}$} & \multicolumn{2}{|c|}{$\begin{array}{c}\text { Methylation } \\
\text { status of BCL2L10 }\end{array}$} & \multirow[b]{2}{*}{$\mathrm{p}$-value } \\
\hline & M & $\mathrm{U}$ & \\
\hline \multicolumn{4}{|l|}{ Sex } \\
\hline Male (14) & 2 & 12 & 0.14 \\
\hline Female (7) & 3 & 4 & \\
\hline \multicolumn{4}{|l|}{ Age } \\
\hline$\leq 65(6)$ & 1 & 5 & 0.63 \\
\hline$>65(15)$ & 3 & 12 & \\
\hline \multicolumn{4}{|l|}{ Location } \\
\hline Upper (6) & 2 & 4 & \\
\hline Middle (5) & 1 & 4 & 0.81 \\
\hline Lower (10) & 2 & 8 & \\
\hline \multicolumn{4}{|l|}{ IM } \\
\hline Present (10) & 2 & 8 & 0.7 \\
\hline Absent (11) & 3 & 8 & \\
\hline \multicolumn{4}{|l|}{ Atrophy } \\
\hline Present (15) & 5 & 10 & 0.11 \\
\hline Absent (6) & 0 & 6 & \\
\hline \multicolumn{4}{|l|}{ H.pylori } \\
\hline Present (9) & 3 & 6 & 0.37 \\
\hline Absent (12) & 2 & 10 & \\
\hline \multicolumn{4}{|l|}{ p16 methylation } \\
\hline Present (5) & 3 & 2 & 0.03 \\
\hline Absent (16) & 2 & 14 & \\
\hline \multicolumn{4}{|l|}{ RUNX3 methylation } \\
\hline Present (4) & 0 & 4 & 0.21 \\
\hline Absent (17) & 5 & 12 & \\
\hline \multicolumn{4}{|l|}{ hMLH1 methylation } \\
\hline Present (1) & 0 & 1 & 0.57 \\
\hline Absent (20) & 5 & 15 & \\
\hline \multicolumn{4}{|l|}{ EZH2 expression } \\
\hline Present (2) & 0 & 2 & 0.41 \\
\hline Absent (19) & 5 & 14 & \\
\hline
\end{tabular}

Differences were analyzed statistically by $\chi^{2}$ test. M, methylated; U, unmethylated.

of $21(48 \%)$ gastric cancer tissues, whereas it was detectable in 2 of $21(9.5 \%)$ non-neoplastic mucosae, indicating EZH2 expression might be elevated in gastric cancer. We assessed the relationship between the expression pattern of EZH2 and the methylation status of each gene, but there was no apparent correlation in the gastric cancer tissues examined.

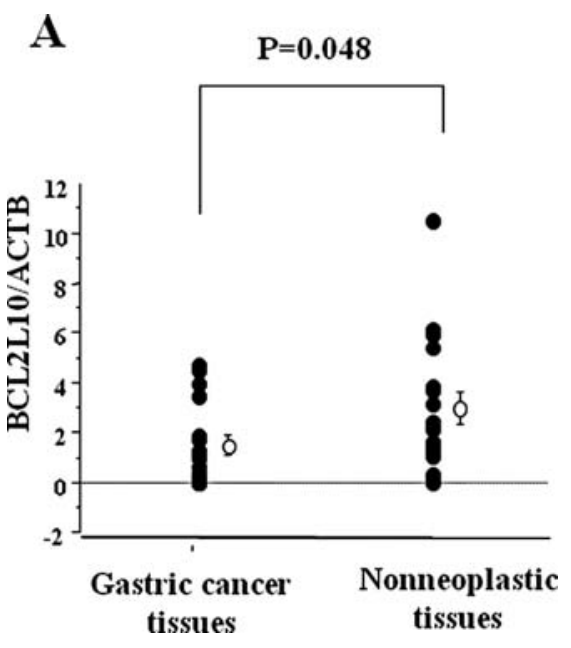

B
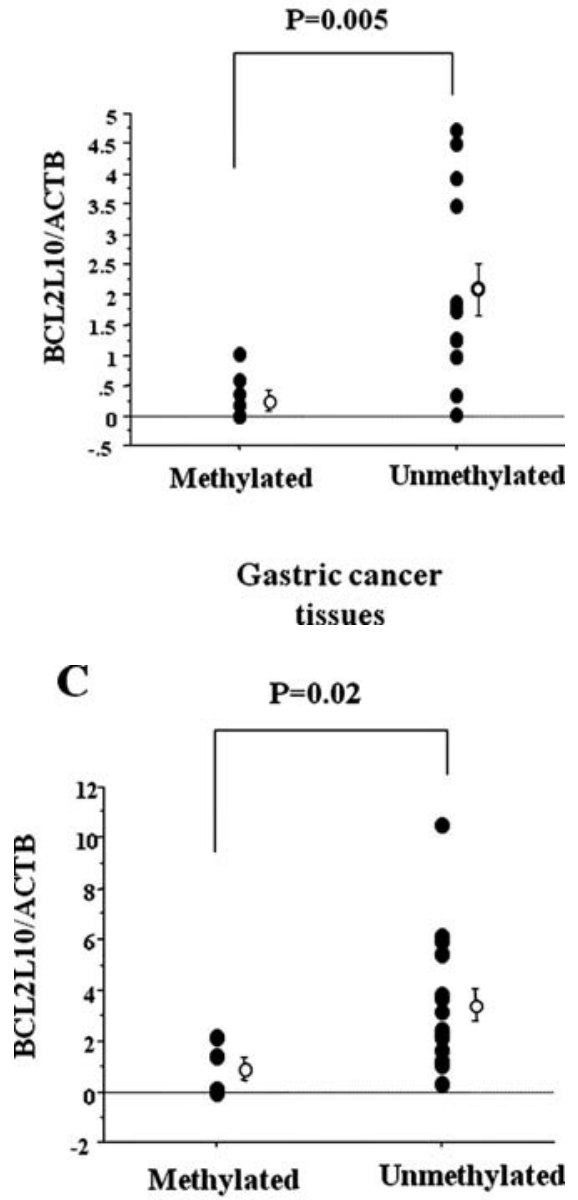

\section{Nonneoplastic tissues}

Figure 3. Expression analysis of BCL2L10 by quantitative RT-PCR. (A) BCL2L10 expression was analyzed in 21 gastric carcinoma specimens and corresponding non-neoplastic mucosae. The expression level of BCL2L10 in tumors was significantly lower than in corresponding non-neoplastic mucosae $(\mathrm{p}=0.048)$. (B) Among the 21 tumors, 8 tumors with methylated BCL2L10 showed significantly lower expression of BCL2L10 than 13 tumors without methylation $(\mathrm{p}=0.005)$. (C) Among the 21 corresponding non-neoplastic mucosae, 5 subjects with methylated BCL2L10 also showed significantly lower expression of BCL2L10 than 16 subjects without methylation $(\mathrm{p}=0.02)$. Open circle and vertical bar indicate average and SEM, respectively. Statistical significance was determined using the Mann-Whitney $\mathrm{U}$ tests. 


\section{Discussion}

In our previous study using cDNA microarray and real-time PCR, five genes were identified to be up-regulated by DAC treatment in gastric cancer cell lines (7). Of these, BCL2L10 was hypermethylated in 4 of 5 gastric cancer cell lines, and its $\mathrm{CpG}$ island became demethylated with the restoration of its expression after DAC treatment. We also observed that overexpression of BCL2L10 caused apoptosis and growthinhibition of gastric cancer cells.

In this study, we used 21 gastric cancer tissues and corresponding non-neoplastic mucosae for investigation of BCL2L10 methylation. As a result, aberrant methylation of BCL2L10 was detected in $38 \%$ of gastric cancer and correlated with its low expression, indicating that silencing of BCL2L10 by promoter methylation is a relatively common feature in gastric cancer. According to our previous results, the epigenetic inactivation of BCL2L10 may lead to a loss of apoptosis, and its inactivation by aberrant methylation may be involved in a critical step of gastric cancer development.

MSP analysis demonstrated that methylation of $\mathrm{p} 16$, RUNX3, and hMLH1 genes occurred in 43, 48, and 10\% of the gastric cancer samples, respectively, consistent with previous reports (21-23). Interestingly, BCL2L10 methylation correlated with p16 methylation status not only in gastric cancer but also in non-neoplastic mucosae, suggesting that a similar mechanism underlies the regulation of methylation status of these genes. Further studies to define the epigenetic regulation of these genes will be necessary.

Regarding non-neoplastic gastric mucosae, aberrant methylation of BCL2L10 was also observed in $24 \%$, while methylation of p16, RUNX3, and hMLH1 was found in 24, 19 , and $5 \%$, respectively. These results are consistent with previous reports $(21,25)$. In recent years, methylation of several $\mathrm{CpG}$ islands in non-tumorous gastric tissue has been described, especially for the exon 1 region of p16. Jang et al showed that p16 methylation was observed in $59 \%$ of the non-tumor tissue samples adjacent to gastric cancer and correlated with the presence of grandular atrophy and the grade of chronic inflammation (24). It also has been reported that methylation of p16 and hMLH1 was more frequent in non-neoplastic gastric epithelia of gastric cancer patients than those of non-gastric cancer patients, suggesting these genes may be utilized as predictors of gastric cancer (26). Maekita et al reported that methylation levels of specific $\mathrm{CpG}$ islands including p16 in non-cancerous gastric mucosa were higher in gastric cancer patients than in age-matched healthy volunteers among $H$. pylori-negative patients using quantitative analysis of methylation (27). In this study, BCL2L10 and p16 methylation were detected in the subjects with atrophy regardless of the presence of IM, whereas no methylation of these genes was detected in the subjects without atrophy. These data suggest that BCL2L10 and p16 methylation might be frequent and early events during the process of gastric carcinogenesis and that BCL2L10 methylation may also serve as a risk marker for the development of gastric cancer. To elucidate the exact prevalence of BCL2L10 methylation in non-neoplastic gastric mucosae, studies of gastric mucosae with non-gastric cancer individuals are needed.
$\mathrm{EZH} 2$, a Polycomb group protein, is known to function in histone methylation, thereby regulating gene expression $(13,14)$. Recently, it has been reported that EZH2 was overexpressed in a variety of human malignancies including gastric cancer $(11,12)$. In another report, EZH2 was demonstrated to be required for DNA methylation of its target genes such as the MYT1 gene (15). In mammals, specific DNA sequences that EZH2 recognize as targets have yet to be identified, and target genes of EZH2 are, therefore, still undetermined. In the current study, expression of EZH2 was detected more frequently in tumors (48\%) compared with corresponding non-neoplastic mucosae (10\%). However, no significant difference was found between expression of EZH2 and methylation frequency of each gene. It is possible that EZH2 might not influence the methylation status of these genes.

$H$. pylori infection is thought to be an important etiologic risk factor in gastric cancer, and it has been classified as a group of definite carcinogen (28). Some specific $\mathrm{CpG}$ islands in $H$. pylori-positive healthy volunteers have been reported to have markedly elevated levels of methylation compared with $H$. pylori-negative counterparts (27). Conversely, it has been also reported that $H$. pylori infection did not correlate with the methylation status of several genes in non-neoplastic gastric mucosa $(25,29)$. In the present study, no correlation was found between methylation of the four genes and presence of $H$. pylori infection. As $H$. pylori infection was evaluated only with histological examination in this study, we can not exclude the possibility of the presence of $H$. pylori in other sites that were not biopsied nor the previous location of $H$. pylori.

In conclusion, our data suggest that silencing of BCL2L10 by aberrant methylation is a common feature in gastric cancer, and its inactivation may be involved in the early steps of gastric carcinogenesis, although further investigation in larger numbers of patients is required.

\section{References}

1. Song SH, Jong HS, Choi HH, Kang SH, Ryu MH, Kim NK, Kim WH and Bang YJ: Methylation of specific $\mathrm{CpG}$ sites in the promoter region could significantly down-regulate p16 (INK4a) expression in gastric adenocarcinoma. Int J Cancer 87: 236-240, 2000.

2. Li QL, Ito K, Sakakura C, Fukamachi H, Inoue K, Chi XZ, Lee KY, Nomura S, Lee CW, Han SB, Kim HM, Kim WJ, Yamamoto H, Yamashita N, Yano T, Ikeda T, Itohara S, Inazawa J, Abe T, Hagiwara A, Yamagishi H, Ooe A, Kaneda A, Sugimura T, Ushijima T, Bae SC and Ito Y: Causal relationship between the loss of RUNX3 expression and gastric cancer. Cell 109: 113-124, 2002.

3. Leung SY, Yuen ST, Chung LP, Chu KM, Chan AS and Ho JC: hMLH1 promoter methylation and lack of hMLH1 expression in sporadic gastric carcinomas with high-frequency microsatellite instability. Cancer Res 59: 159-164, 1999.

4. Satoh A, Toyota M, Itoh F, Sasaki Y, Suzuki H, Ogi K, Kikuchi T, Mita H, Yamashita T, Kojima T, Kusano M, Fujita M, Hosokawa M, Endo T, Tokino T and Imai K: Epigenetic inactivation of CHFR and sensitivity to microtubule inhibitors in gastric cancer. Cancer Res 63: 8606-8613, 2003.

5. Park J, Song SH, Kim TY, Choi MC, Jong HS, Kim TY, Lee JW, Kim NK, Kim WH and Bang YJ: Aberrant methylation of integrin alpha4 gene in human gastric cancer cells. Oncogene 23: 3474-3480, 2004

6. Obata T, Toyota M, Satoh A, Sasaki Y, Ogi K, Akino K, Suzuki H, Murai M, Kikuchi T, Mita H, Itoh F, Issa JP, Tokino T and Imai K: Identification of HRK as a target of epigenetic inactivation in colorectal and gastric cancer. Clin Cancer Res 9: 6410-6418, 2003. 
7. Mikata R, Yokosuka O, Fukai K, Imazeki F, Arai M, Tada M, Kurihara T, Zhang K, Kanda T and Saisho H: Analysis of genes upregulated by the demethylating agent 5-aza-2'deoxycytidine in gastric cancer cell lines. Int J Cancer 119: 1616-1622, 2006.

8. Inohara N, Gourley TS, Carrio R, Muniz M, Merino J, Garcia I, Koseki T, Hu Y, Chen S and Nunez G: Diva, a Bcl-2 homologue that binds directly to Apaf-1 and induces BH3-independent cell death. J Biol Chem 73: 32479-32486, 1998.

9. Naumann U, Weit S, Wischhusen J and Weller M: Diva/Boo is a negative regulator of cell death in human glioma cells. FEBS Lett 505: 23-26, 2001.

10. Ke N, Godzik A and Reed JC: Bcl-B, a novel Bcl-2 family member that differentially binds and regulates Bax and Bak. J Biol Chem 276: 12481-12484, 2001.

11. Bracken AP, Pasini D, Capra M, Prosperini E, Colli E and Helin K: EZH2 is downstream of the pRB-E2F pathway, essential for proliferation and amplified in cancer. EMBO J 22: 5323-5335, 2003.

12. Matsukawa Y, Semba S, Kato H, Ito A, Yanagihara K and Yokozaki H: Expression of the enhancer of zeste homolog 2 is correlated with poor prognosis in human gastric cancer. Cancer Sci 97: 484-491, 2006.

13. Cao R, Wang L, Wang H, Xia L, Erdjument-Bromage H, Tempst P, Jones RS and Zhang Y: Role of histone H3 lysine 27 methylation in Polycomb-group silencing. Science 298: 1039-1043, 2002.

14. Czermin B, Melfi R, McCabe D, Seitz V, Imhof A and Pirrotta V: Drosophila enhancer of Zeste/ESC complexes have a histone H3 methyltransferase activity that marks chromosomal Polycomb sites. Cell 111: 185-196, 2002.

15. Vire E, Brenner C, Deplus R, et al: The Polycomb group protein EZH2 directly controls DNA methylation. Nature 439: 871-874, 2006.

16. Japanese Gastric Cancer Association. Japanese Classification of Gastric Carcinoma. 2nd English Edition. Gastric Cancer 1: 10-24, 1998

17. Herman JG, Graff JR, Myohanen S, Nelkin BD and Baylin SB: Methylation-specific PCR: a novel PCR assay for methylation status of CpG islands. Proc Natl Acad Sci USA 93: 9821-9826, 1996.

18. Goel A, Arnold CN, Tassone P, Chang DK, Niedzwiecki D, Dowell JM, Wasserman L, Compton C, Mayer RJ, Bertagnolli MM and Boland CR: Epigenetic inactivation of RUNX3 in microsatellite unstable sporadic colon cancers. Int J Cancer 112: 754-759, 2004.
19. Kang GH, Shim YH and Ro JY: Correlation of methylation of the hMLH1 promoter with lack of expression of hMLH1 in sporadic gastric carcinomas with replication error. Lab Invest 79: 903-909, 1999.

20. Raman JD, Mongan NP, Tickoo SK, Boorjian SA, Scherr DS and Gudas LJ: Increased expression of the polycomb group gene, EZH2, in transitional cell carcinoma of the bladder. Clin Cancer Res 11: 8570-8576, 2005.

21. Kang GH, Shim YH, Jung HY, Kim WH, Ro JY and Rhyu MG: $\mathrm{CpG}$ island methylation in premalignant stages of gastric carcinoma. Cancer Res 61: 2847-2851, 2001.

22. Oue N, Oshimo Y, Nakayama H, Ito R, Yoshida K, Matsusaki K and Yasui W: DNA methylation of multiple genes in gastric carcinoma: association with histological type and $\mathrm{CpG}$ island methylator phenotype. Cancer Sci 94: 901-905, 2003.

23. Waki T, Tamura G, Sato M, Terashima M, Nishizuka S and Motoyama T: Promoter methylation status of DAP-kinase and RUNX3 genes in neoplastic and non-neoplastic gastric epithelia. Cancer Sci 94: 360-364, 2003.

24. Jang TJ, Kim DI, Shin YM, Chang HK and Yang CH: p16(INK4a) Promoter hypermethylation of non-tumorous tissue adjacent to gastric cancer is correlated with glandular atrophy and chronic inflammation. Int J Cancer 93: 629-634, 2001.

25. Kang GH, Lee HJ, Hwang KS, Lee S, Kim JH and Kim JS: Aberrant $\mathrm{CpG}$ island hypermethylation of chronic gastritis, in relation to aging, gender, intestinal metaplasia, and chronic inflammation. Am J Pathol 163: 1551-1556, 2003.

26. Tamura G: Promoter methylation status of tumor suppressor and tumor-related genes in neoplastic and non-neoplastic gastric epithelia. Histol Histopathol 19: 221-228, 2004.

27. Maekita T, Nakazawa K, Mihara M, Nakajima T, Yanaoka K, Iguchi M, Arii K, Kaneda A, Tsukamoto T, Tatematsu M, Tamura G, Saito D, Sugimura T, Ichinose M and Ushijima T: High levels of aberrant DNA methylation in Helicobacter pylori-infected gastric mucosae and its possible association with gastric cancer risk. Clin Cancer Res 12: 989-995, 2006.

28. IARC working group on the evaluation of carcinogenic risks to humans, schistosomes, liver flukes, helicobacter pylori. IARC Monographs on the Evaluation of Carcinogenic Risks to Humans. Vol 61. International Agency for Research on Cancer, Lyon, 1994.

29. Oue N, Mitani Y, Motoshita J, Matsumura S, Yoshida K, Kuniyasu H, Nakayama $\mathrm{H}$ and Yasui W: Accumulation of DNA methylation is associated with tumor stage in gastric cancer. Cancer 106: 1250-1259, 2006. 